Artigo recebido em 03.03.2020 / Aprovado em 07.05.2020

\title{
A LEI 11.689/2008 E O TRIBUNAL DO JÚRI NO BRASIL: ASPECTOS CRÍTICOS DOUTRINÁRIOS E JURISPRUDENCIAIS
}

\section{THE LAW 11.689/2008 AND THE JURY COURT IN BRAZIL: DOCTRINAL AND JURISPRUDENTIAL CRITICAL ASPECTS}

\author{
Kamila Câmera ${ }^{1}$ \\ Tarsis Barreto Oliveira ${ }^{2}$
}

\section{RESUMO}

O presente artigo utiliza o embasamento teórico para expor possíveis violações de fundamentos constitucionais que ocorrem durante os debates no Tribunal do Júri, especificamente quanto ao crime de homicídio. Inicialmente, discorre-se sobre o instituto do Tribunal do Júri, tratando de sua evolução histórica e de seu posicionamento na Constituição Federal, tornando-o cláusula pétrea, bem como dos seus princípios próprios. Aborda-se a vinculação entre os debates e possíveis violações à Constituição Federal. Demonstra-se o caráter simbólico e arcaico do instituto, prevalecendo a encenação das partes sobre o processo em si, a importância da tecnicidade coloquial da acusação e da defesa em plenário, para que o Conselho de Sentença seja capaz de compreender as normas jurídicas ali debatidas e, consequentemente, ter discernimento no momento da votação dos quesitos, para não comprometer o resultado do julgamento. Conclui-se pela imprescindibilidade das partes buscarem aproximação linguística com o conhecimento dos jurados leigos, manterem o foco no processo em discussão e valorizarem o réu e a vítima, muitas vezes marginalizados em detrimento do privilégio das encenações das partes.

PALAVRAS-CHAVE: debates; homicídio; jurados; tribunal do júri.

\footnotetext{
${ }^{1}$ Pós-graduada em Direito Público com Ênfase em Gestão Pública pela Faculdade IBMEC São Paulo. Graduada em Direito pela Universidade Federal do Tocantins. E-mail: camerakamila@gmail.com. ID ORCID n. 0000-0003-1691-7828.

2 Doutor e Mestre em Direito pela UFBA. Professor Associado de Direito Penal da Universidade Federal do Tocantins. Professor Adjunto de Direito Penal da Universidade Estadual do Tocantins. Membro do Comité International des Pénalistes Francophones e da Association Internacionale de Droit Pénal. E-mail: tarsisbarreto@uft.edu.br. ID ORCID n. 000-0003-0931-8915.
} 


\begin{abstract}
This article uses the theoretical basis to expose the violations of constitutional foundations that occur during the debates in the Court of the Jury, specifically regarding the crime of homicide. Initially, it focuses on the institute of the Court of the Jury, dealing with its historical evolution and its position in the Federal Constitution, making it a stony clause, as well as its own principles. The link between debates and violations of the Federal Constitution is discussed. It demonstrates the symbolic and archaic character of the institute, where the role of the parties prevails over the process itself, the importance of colloquial technicity of prosecution and defense in plenary, so that the Judgment Council is able to understand the legal norms there debated and, consequently, to have discernment at the moment of voting of the questions, in order not to compromise the result of the judgment. It is concluded that it's essential for the parties to seek a linguistic approach with the knowledge of lay jurors, to keep the focus on the process under discussion and to value the defendant and the victim, who are often marginalized so that the parties prevail in their own scenarios.
\end{abstract}

KEYWORDS: debates; murder; judges; jury court.

\title{
1 INTRODUÇÃO
}

Este artigo utiliza a revisão, a discussão teórico-bibliográfica e a pesquisa qualitativa, para tratar sobre o tribunal do júri, com enfoque no momento dos debates entre as partes, onde surgem vários posicionamentos e argumentos pretensiosos que contrariam disposições constitucionais.

Diversos doutrinadores, autores de artigos científicos, bem como jurisprudências e legislações pátrias, foram utilizados como fundamento neste trabalho, nutrindo-o com posicionamentos que convergem em um só ponto: as significativas contradições em face do ordenamento constitucional.

Considerando que o instituto está previsto na Constituição Federal, em seu art. $5^{\circ}$, XXXVIII, parece falaciosa a sustentação de que pode haver vilipêndios a outras normas inseridas no mesmo capítulo, mas o contrário se fará presente neste estudo.

Tanto a acusação, representada pelo Ministério Público, quanto a defesa, exercida pela Defensoria Pública ou por advogado, utilizam de artifícios persuasivos para lograrem êxito com seus argumentos, os quais, muitas vezes, são ausentes de técnica, zelo e altruísmo. 
Tais imposições são absorvidas pelo Conselho de Sentença, composto por sete pessoas da sociedade, normalmente leigas sobre os assuntos jurídicos e tecnicamente incapazes de fazer juízo de valor sobre o que lhes é dito, alçando impropriedades à condição de verdades ensejadoras de absolvição ou condenação.

Essa condição ultrapassada do tribunal do júri prejudica o ordenamento como um todo, diante da sua intangibilidade e proteção constitucional, obstando, até mesmo, debates mais profundos sobre o tema.

Assim, este artigo possui o condão de discutir as posições de personagens principais que as partes assumem em plenário, externando informações desconexas e indutivas, distanciando-se da técnica jurídica e da capacidade de compreender que o instituto não deve ser visto como mero teatro de encenações pessoais, mas, sim, como um momento digno de respeito, capaz de modificar e deixar marcas eternas no futuro de vários indivíduos.

\section{O TRIBUNAL DO JÚRI}

\subsection{Breve evolução histórica}

A origem do instituto ainda é bastante discutida na doutrina por conta da sua imprecisão, mas permanece conectada à ideia de julgamento pelos próprios pares ou pela sociedade de forma direta (ISHIDA, 2009, p. 208). Por mais que seja dominante o posicionamento de que se originou na Magna Carta da Inglaterra em 1215, já havia marcas muitos anos antes.

Ele foi instituído no Brasil pela Lei de 28 de junho de 1822, voltado aos delitos de imprensa (OLIVEIRA, 2009, p. 635), por decreto do Príncipe Regente (OLIVEIRA, 2017, p. 241). Possui raízes no direito francês e era composto por 24 cidadãos, escolhidos dentre os homens bons, honrados, inteligentes e patriotas, motivo que já carregou o instituto de questionamentos, pois na sociedade escravocrata da época só atenderiam esses requisitos os homens que pudessem ser eleitos, que possuíssem renda e que pertencessem às camadas dominantes (STRECK, 2001, p. 87). 
O instituto firmou-se como tal na Constituição de 1824 - Constituição de Império -, sendo disposto no capítulo referente ao Poder Judiciário (art. 151, Capítulo Único, Título 6). $\mathrm{Na}$ época, os jurados eram competentes para julgar tanto as causas cíveis quanto as criminais, de acordo com a lei, e vários delitos foram excluídos e incluídos de sua competência (NUCCl, 2015, p. 58).

$\mathrm{Na}$ Constituição Federal de 1988, está inserido no Título II - Dos Direitos e Garantias Fundamentais, Capítulo I - Dos Direitos e Deveres Individuais e Coletivos, no art. $5^{\circ}, \mathrm{XXXVIII,} \mathrm{in} \mathrm{verbis:}$

Art. 5ำ Todos são iguais perante a lei, sem distinção de qualquer natureza, garantindo-se aos brasileiros e aos estrangeiros residentes no País a inviolabilidade do direito à vida, à liberdade, à igualdade, à segurança e à propriedade, nos termos seguintes:

XXXVIII - é reconhecida a instituição do júri, com a organização que lhe der a lei, assegurados:

a) a plenitude de defesa;

b) o sigilo das votações;

c) a soberania dos veredictos;

d) a competência para o julgamento dos crimes dolosos contra a vida.

Conforme a disposição constitucional, possui competência absoluta para julgar os crimes dolosos contra a vida, os quais inauguram a Parte Especial do Código Penal Brasileiro e estão dispostos do art. 121 ao 127, que representam os crimes de homicídio, induzimento, instigação ou auxílio a suicídio, infanticídio e aborto.

Além disso, caso haja conexão entre um crime doloso contra a vida e outro da competência originária de juiz singular, prevalecerá a do primeiro, nos moldes do art. 78, I, do CPP, exceção que autoriza o julgamento de outros delitos pelo tribunal do júri.

Sete jurados comporão o Conselho de Sentença, sorteados em cada sessão de julgamento dentre o total de vinte e cinco alistados. "O serviço do júri é obrigatório e sem remuneração para o cidadão." (STRECK, 2001, p. 97).

A recusa injustificada acarretará multa no valor de 1 (um) a 10 (dez) salários mínimos (art. 436, § 2o, do CPP), e se for fundada em convicção religiosa, filosófica ou política, ensejará no dever de prestar serviço alterativo, sob pena de suspensão dos direitos políticos enquanto não concluir o serviço (art. 438, caput, do CPP). 
O procedimento especial do júri está disposto nos artigos 406 ao 497 do Código de Processo Penal.

\subsection{Os princípios fundamentais}

Os princípios dispostos na Constituição Federal podem ser considerados como a base do sistema normativo, pois as normas infraconstitucionais devem se ater às suas disposições (NUCCl, 2015, p. 33).

O tribunal do júri é garantido como cláusula pétrea, conforme o art. 60 , § 4º, IV, da CF, assim como seus princípios fundamentais, os quais norteiam todo o rito. Todavia, da mesma forma como criam garantias irrefutáveis, impedem que o instituto seja questionado e que sofra alterações naturais ante o desenvolvimento da sociedade e do Direito, mantendo-o com caráter e rituais antigos, gerando questionamentos quando à idoneidade e necessidade do instituto.

As alíneas $a, b$ e $c$ do inciso XXXVIII, do art. 5ํ, da CF, elencam os princípios fundamentais do tribunal do júri: a plenitude de defesa, o sigilo das votações e a soberania dos vereditos.

\subsubsection{A plenitude de defesa}

O alcance da defesa postulada no contexto do júri consegue ir além da existente nos procedimentos comuns, pois se trata de plenitude e não de ampla defesa, sendo esta uma garantia básica de todos.

Todas as palavras dispostas nas normas devem ser consideradas, não havendo nada inútil ou, no caso das normas relativas ao júri, que apenas repita as disposições da Constituição de 1946. Amplo é algo vasto, largo, copioso, enquanto que pleno equivale a completo, perfeito, absoluto, restando evidente a intenção do legislador em enfatizar a diferença entre ambos.

Consequentemente, em plenário busca-se a defesa perfeita, a qual poderá se sujeitar à limitação apenas quanto às questões naturais do ser humano. Quando se 
nota que o réu não possui esse direito básico, deve ser declarado indefeso e obter outro defensor (NUCCl, 2015, p. 34-35).

Não se pode conceber a plenitude da defesa, simplesmente como o direito do réu de ser assistido por um advogado. Importante que se the assegure a escolha de um profissional de sua confiança, capacitado e com disponibilidade de tempo para tratar dos seus interesses. Isso seria ideal.

A plenitude se revela, ainda, na garantia da realização das investigações que antecedem à sentença de pronúncia, necessárias à formação da convicção quanto à remessa do feito a julgamento pelo Tribunal do Júri e das diligências subsequentes, necessárias ao embasamento da tese defensiva a ser apresentadas aos jurados quando do julgamento em plenário. (DUTRA, 2008, p.10)

Considerando que o júri trata dos bens mais preciosos do ordenamento jurídico (vida, liberdade etc), a cautela do defensor deve ser redobrada, pois qualquer falha pode conduzir à condenação do acusado, já que são jurados leigos que decidirão de acordo com as teses levantadas em plenário e com suas convicções pessoais. Dessa monta, a atuação, básica, regular, coloca em risco, seriamente, a liberdade do réu.

Não obstante, é fundamental que o juiz presidente controle, ativamente, a eficiência da defesa do acusado ( $\mathrm{NUCCl}, 2015$, p. 36).

A plenitude de defesa também alcança a composição do Conselho de Sentença, que deve contar com representantes dos mais diversos seguimentos da sociedade para que seja formado por várias realidades, compreensões, e que não seja marcado por apenas uma classe social ou um ideal dominante (NETO, 2017, p. 79).

\subsubsection{Sigilo das votações}

Conforme dispõe o art. 485, caput, do CPP, "o juiz presidente, os jurados, o Ministério Público, o assistente, o querelante, o defensor do acusado, o escrivão e o oficial de justiça dirigir-se-ão à sala especial a fim de ser procedida a votação". Não havendo sala especial, será determinado pelo juiz presidente que o público se retire do local, permanecendo somente as pessoas mencionadas no artigo (art. 485 , $\S 1^{\circ}$, do CPP). 
A inconstitucionalidade da sala secreta é motivo de grande discussão. Alguns entendem que há violação à garantia de publicidade dos atos processuais, conforme o disposto no art. 5, LX da CF: "a lei só poderá restringir a publicidade dos atos processuais quando a defesa da intimidade ou o interesse social o exigirem", bem como no art. 93, IX da CF, a saber:

todos os julgamentos dos órgãos do Poder Judiciário serão públicos, e fundamentadas todas as decisões, sob pena de nulidade, podendo a lei limitar a presença, em determinados atos, às próprias partes e a seus advogados, ou somente a estes, em casos nos quais a preservação do direito à intimidade do interessado no sigilo não prejudique o interesse público à informação.

Nesse sentido, Cabral Jr. apud Tourinho Filho (2017, p. 89):

Há entendimento no sentido de que a "sala secreta" não mais se justifica. Na verdade, o que a Constituição exige é a sigilação na votação. Nada impede, pois, se proceda à votação coram populo [diante do povo], dês que preservado o sigilo. Aliás, ocorrendo a votação em plenário, o julgamento sobre se tornar mais democrático torna-se fiscalizável pelo olho do povo.

É de se considerar que o Conselho de Sentença brasileiro não se assemelha ao norte americano, no qual os jurados podem discutir sobre o caso que thes foi exposto para chegarem a uma decisão racional e pretensamente justa. Tal comunicação pode ser benéfica, pois dúvidas surgem quando se debate qualquer assunto, e os jurados podem dirimi-las fazendo perguntas às partes, tornando o julgamento possivelmente mais seguro.

O que parece é que a regra da incomunicabilidade dos jurados entrega uma visão sombria ao instituto, além de afastar a previsibilidade de que estão sendo racionais e justos em seus posicionamentos. É descabido considerar que a vida de alguém está condicionada aos pensamentos aleatórios, inseguros, desconexos e sem embasamento técnico, que preenchem a sala secreta no momento da votação. 


\subsubsection{Soberania dos vereditos}

O último princípio disposto no art. 5, XXXVIII, da CF, completa o ideal de arbitrariedade inerente ao Conselho de Sentença, pois ele não precisa fundamentar ou justificar cada votação ou o resultado do julgamento, permitindo que o jurado emita, por meio do voto, sua convicção (OLIVEIRA, 2009, p. 636).

É soberana a decisão que não pode ser contestada sobre seu mérito em outro tribunal togado. Todavia, a soberania do júri é relativa, pois, conforme preleciona o art. 593, III, do CPP, caberá apelação das decisões do tribunal do júri quando: a) ocorrer nulidade posterior à pronúncia; b) for a sentença do juiz-presidente contrária à lei expressa ou à decisão dos jurados; c) houver erro ou injustiça no tocante à aplicação da pena ou da medida de segurança; ou d) for a decisão dos jurados manifestamente contrária à prova dos autos (NUCCl, 2015, p. 43).

O recurso de apelação será interposto ao Tribunal de Justiça que, se decidir cassar a decisão dos jurados, devolverá o processo para que seja submetido a um segundo julgamento, com novo Conselho de Sentença, abrindo margem para a ocorrência de uma decisão completamente oposta à anterior (SANTOS NETO, 2017, p. 81).

Os precedentes da Suprema Corte brasileira coadunam à prevalência da soberania dos vereditos e a realização de novo julgamento:

Sendo a qualificadora do crime matéria submetida ao corpo de jurados, a apelação que a tiver como fundamento deverá ser interposta com base na alínea $d$ do inciso III do art. 593 do CPP, renovando-se o júri em caso de provimento. É que, se o próprio tribunal togado reformasse a sentença, não haveria mera correção de pena, mas desrespeito à decisão dos jurados reconhecedora ou não da tipicidade derivada, com evidente afronta à soberania dos vereditos. (HC n. 122.320, Rel. Min. Teori Zavascki, julgado em 24/3/2015, 2 $2^{\text {a }}$ Turma, publicado em 3/8/2015);

A soberania dos veredictos do tribunal do júri, prevista no art. 5ํㅡㄴ XXXVIII, $c$, da CF, resta afrontada quando o acórdão da apelação acolhe a tese de contrariedade à prova dos autos (art. 593, III, d, do CPP) e prestigia uma das versões verossímeis do fato, em detrimento daquela escolhida pelo Conselho de Sentença. (RHC n. 122.497, Rel. mMin. Luiz Fux, julgado em 2/9/2014, $1^{\text {a }}$ Turma, publicado em 23-9-2014); 
Fere o princípio da soberania dos veredictos a afirmação peremptória do magistrado, na sentença de pronúncia, que se diz convencido da autoria do delito. A decisão de pronúncia deve guardar correlação, moderação e comedimento com a fase de mera admissibilidade e encaminhamento da ação penal ao tribunal do júri. (HC n. 93.299, Rel. Min. Ricardo Lewandowski, julgado em 16/9/2008, Primeira Turma, publicado em 24/10/2008.);

Sendo do tribunal do júri a competência para julgar crime doloso contra a vida, descabe a órgão revisor, apreciando recurso em sentido estrito, absolver o agente e impor medida de segurança. (HC n. 87.614, Rel. Min. Marco Aurélio, julgado em 3/4/2007, Primeira Turma, publicado em 15-6-2007).

Como se denota, o STF garante a incidência do princípio da soberania dos vereditos desde a decisão de pronúncia, na qual o juiz deverá considerar que a competência para julgar os crimes dolosos contra a vida é do tribunal do júri, e que prevalece a decisão do Conselho de Sentença desde que vinculada aos autos, pois, do contrário, é cabível recurso de apelação.

\section{OS DEBATES}

Eis o ápice do rito escalonado. Os debates são inaugurados com a concessão da palavra ao Ministério Público, que disporá de uma hora e trinta minutos para a acusação, limitando-se aos termos da pronúncia ou de decisões posteriores que admitiram a acusação (arts. 476 e 477 do CPP).

Caso haja assistente de acusação, este terá a palavra após o Ministério Público (art. 476, $\S 1^{\circ}$, do CPP), e a disposição do tempo será combinada pelos acusadores (art. 477, § 1ำ, do CPP).

Na sequência, a defesa disporá, também, de uma hora e trinta minutos para sustentação de suas teses (arts. 476, § 3ํㅡㄹ e 477, caput, do CPP). Caso haja mais de um defensor, os mesmos decidirão quanto à divisão do tempo (art. 477, § 1ํ, do CPP).

Se entender necessário, a acusação poderá replicar a sustentação feita pela defesa pelo tempo de uma hora, abrindo espaço à tréplica, nos termos dos arts. $476, \S$ $4^{\circ}$, e 477, caput, do CPP. 
Nesse ponto, já é possível perceber um dos problemas do rito, pois a defesa será prejudicada se for incapaz de expor com clareza e tecnicidade as teses que possui na primeira parte dos debates. É um erro crasso deixá-las para a tréplica, pois, se o Parquet notar a manobra e dispensar a réplica, as sustentações serão encerradas e não existirá outro momento para que a defesa fale, havendo grave violação ao princípio da plenitude de defesa (LOPES JR., 2012, p. 1.031).

Se, porventura, houver mais de um acusado, ao tempo disponibilizado à acusação e à defesa será acrescida uma hora, sendo os períodos de réplica e tréplica dobrados (art. 477, § $2^{\circ}$, do CPP).

Entretanto, não há vantagem alguma para a defesa em realizar o julgamento de vários acusados, pelo fato de que ter dois ou dez réus apenas concederá o tempo máximo de duas horas e meia para a sustentação oral, sendo indispensável o pedido de cisão do processo.

Atualmente, entretanto, a reforma dificultou a separação dos julgamentos, de modo que é preciso basear-se no princípio constitucional da plenitude de defesa para não restar a defesa com um prazo exíguo para manifestação.

Excepcionalmente, pode-se admitir a utilização de apenas duas horas e meia para a sustentação eficaz da tese defensiva envolvendo mais de um réu. Tal se dá nos casos em que a linha de defesa é exatamente a mesma (ex.: negativa de autoria para todos). Do contrário, havendo teses variadas e alternativas, seria recomendável a cisão, para que cada defensor tivesse uma hora e meia integrais para sustentar sua argumentação. Aliás, deve o juiz presidente, de ofício, zelando pela aplicação do princípio constitucional da plenitude de defesa, analisar se a existência de vários réus, contando com diferentes defensores, em apenas duas horas e meia, não constituirá um sério gravame para a exposição das teses. Caso essa hipótese se concretize, o magistrado deve intervir, provocando, se necessário, o desmembramento do processo. Ou, ainda, o aumento do tempo de manifestação para cada defensor. (NUCCI, 2015, p. 330-331)

Nos pontos supracitados, ficam evidenciadas falhas no procedimento atual do tribunal do júri, devido à flagrante violação aos princípios basilares esculpidos na Constituição Federal. Caso haja vários réus a serem julgados no mesmo processo, não Ihes serão garantidos os princípios da plenitude de defesa e do devido processo legal. 


\subsection{O simbolismo nos debates}

Por mais que o procedimento especial do tribunal do júri tenha sofrido alterações recentes, o momento do plenário ainda carrega traços arcaicos e simbólicos.

[...] o mundo social é constituído em função de um sistema de significações. Tais significações existem na forma de um imaginário efetivo. Relativamente a essas significações imaginárias, é que se pode compreender a escolha que cada sociedade faz de seu simbolismo. Fora da categoria do imaginário, é impossível compreender a história humana. [...]

É nesse contexto que o Tribunal do Júri será examinado. Por seu forte componente ritual, as representações imaginárias da sociedade, simbolizadas nos julgamentos, resultam em uma leitura possível dos comportamentos desejados e desejantes da sociedade ali "representada". Isto porque, como bem lembra Gonçalves, os processos simbólicos e míticos assumem importância fundamental na exteriorização das práticas sociais ritualizadas, referentes ao saber e ao saber-fazer de qualquer cultura e sociedade. [...]

O Tribunal do Júri, na medida em que é um ritual por excelência, é uma instituição que (re)articula mensagens diretamente relacionadas com a sociedade a qual representa. No seu interior, os atores (re)produzen (sic), em considerável medida, a própria sociedade. Por isto, o júri é visto, no âmbito (e nos limites) desta obra, como um momento extraordinário que (re)articula e (re)organiza de uma maneira diferente os momentos ordinários da rotina cotidiana da sociedade e, à parte de torná-la passível de ser lida/entendida, institui uma outra rotina, pela qual os agentes sociais venham a "perceber/entender" que as diferenças sociais são "normais", e que a hierarquia da sociedade deve ser preservada e que a lei tem a função de, além de "conceder" chances iguais para todos, "proteger" a totalidade da sociedade, sem distinções de classes sociais, mantendo-se, assim, a ilusão de que vivemos em um corpo social sem fissuras. [...]

Tem-se, então, uma distribuição dos espaços no júri que poderia ser caracterizada como geopolítica. Essa segregação de posições - que existe em qualquer tribunal, mas que é, principalmente, estereotipada no júri -, é tomada pelas pessoas, lembra Correa, como parte do espetáculo: 0 advogado espera que 0 juiz profira as palavras regulamentares; os jurados se dirigem em ordem para seus lugares, ocupando a mesma cadeira toda vez que voltam à sala após uma interrupção, enquanto o réu fica quase sempre com a cabeça baixa entre as mãos ou chorando. [...]

O debate, máscara ao mesmo tempo que realidade, está anteriormente limitado pelas condições de sua produção. Os atores jurídicos, ao servirem de mediadores de uma realidade que não é a sua, perdem de vista o sentido de opressão inscrito no trabalho que realizam, passando a atuar como se, de fato, todos fossem iguais. [...] 
Os mais diferentes tipos de discursos e recursos retóricos são utilizados no plenário. Estilos gongóricos, teatrais, "técnicos"... Alguns julgamentos tornam-se burlescos. ...existem tantas formas e maneiras de atuação em plenário quanto são os protagonistas do espetáculo. (STRECK, 2001, p. 102-114)

Compreende-se, então, que o momento do plenário é uma afirmação das diferenças sociais conduzida pelas partes. Os jurados condenarão aquele comportamento que consideram inaceitável, mas não percebem que não há soberania em uma decisão que foi induzida pelas partes, que utilizam diversos estilos de linguagem para conseguir levar emoção aos ouvintes, distanciando-se, muitas vezes, dos autos processuais.

Streck apud Nassif (2001, p. 115) aduz que existem duas contingências usadas pelas partes em plenário: a) o discurso com grande carga de apelo emocional, persuasivo; e b) a interpretação cênica, teatral.

Para ele, "os réus no Júri são uma minoria sem representatividade moral ou ética eficaz para informar seus pares. É de se lhes permitir comunicarem suas histórias e que têm seu próprio sentido. E, para convencer, por meio de seu defensor, têm que se valer do mesmo universo de linguagem metafórica, imagem de que se valiam os antigos helênicos, com a necessária adaptação à realidade contemporânea e situação nada heroica dos homicidas." E complementa, dizendo que isso também vale para a acusação, uma vez que, "respeitados os limites éticos, se reportar à situação que possa ser vivenciada por qualquer dos integrantes do Conselho de Sentença, este tipo de interpretação é recurso de extrema validade". Assevera que, indubitavelmente, os debates no plenário provocam as mais desencontradas paixões, tanto dos críticos quanto dos defensores da instituição. (p. 115, grifo nosso)

Por esses fundamentos, denota-se que o momento do plenário possui alta carga teatral, com uso dos mais variados argumentos para induzir o Conselho de Sentença a concordar com a tese sustentada pela defesa ou pela acusação.

Ademais, o acusado, mesmo sendo a pessoa que, possivelmente, mais terá a vida impactada pelo resultado do julgamento, possui quase irrelevância neste momento crucial, restando apenas a acusação e a defesa como as protagonistas do momento, atraindo a atenção da "plateia" e até mesmo da mídia com seus discursos. 
Dúvida não há, que o corpo de jurado é composto de pessoas leigas, quase sempre sem conhecimentos jurídicos, podendo facilmente ser ludibriadas pelos argumentos das partes, que nem sempre coincide com a verdade dos fatos, possibilitando a condenação de pessoa inocente. (SILVA, 2016, p. 419).

Diante disso, é clara a possibilidade de violação, novamente, do princípio da plenitude de defesa, do devido processo legal e do acesso à justiça (art. 5ํ, XXXV, da $\mathrm{CF}$ ), já que o fato nem sempre será o foco da discussão entre as partes em plenário, pois poderão discorrer ao Conselho de Sentença e ao público em geral acerca do conhecimento que possuem sobre áreas diversas, além de, não raro, proferirem ataques pessoais entre as instituições, afastando-se, nessas hipóteses, do crime doloso contra a vida.

\subsection{Explanação sobre as qualificadoras e o privilégio no crime de homicídio}

Um momento de extrema relevância - que pressupõe cautela - durante os debates ocorre quando as partes defendem suas teses com embasamento nas qualificadoras ou no privilégio existentes no art. 121 do CP.

A análise dessas circunstâncias do crime deve ser minuciosa, praticamente cirúrgica, pois, caso haja dúvidas quanto à hermenêutica das mesmas, o resultado do julgamento poderá restar gravemente comprometido, já que as partes poderão estar diante de indivíduos sem conhecimento técnico de Direito, sendo possivelmente incapazes de ter raciocínio crítico sobre os argumentos.

A falta de profissionalismo, de estrutura psicológica, aliados ao mais completo desconhecimento do processo e de processo, são graves inconvenientes do Tribunal do Júri. Não se trata de idolatrar o juiz togado, muito longe disso, senão de compreender a questão a partir de um mínimo de seriedade científica, imprescindível para o desempenho do ato de julgar.

Os jurados carecem de conhecimento legal e dogmático mínimo para a realização dos diversos juízos axiológicos que envolvem a análise da norma penal e processual aplicável ao caso, bem como uma razoável valoração da prova. É o grave paradoxo apontado por FAIREN GUILLEN: un juez lego, ignorante de la Ley, no puede aplicar un texto de la Ley porque no la conoce. [...] O julgamento resume-se a folhas mortas. Os jurados desconhecem o Direito e o próprio processo, na 
medida em que se limitam ao trazido pelo debate, ainda que, em tese, tenham acesso a "todo" o processo (como se "todo" fosse apreensível, realmente estivesse no processo e esse processo fosse realmente de conhecimento dos jurados). (LOPES JR., 2012, p. 1050-1051, grifo nosso)

[...] esse é realmente um risco de grandes proporções. Preconceitos, ideias preconcebidas e toda sorte de intolerância podem emergir no julgamento em Plenário, tudo a depender da eficiência retórica dos falantes (Ministério Público, assistente de acusação e defesa). (OLIVEIRA, 2012, p. 710)

A defesa ou a acusação que se expressar melhor, que conseguir tocar mais profundamente os jurados, terá maiores chances de ter sua verdade aceita.

Pelos jurados não possuírem conhecimentos jurídicos, se tornam mais vulneráveis ao convencimento baseado na retórica, e não nas provas efetivamente colhidas nos autos. (OLIVEIRA, 2017, p. 244)

[...] pesam mais para os homens do que para as mulheres, no sentido absolutório em relação ao acusado, os maus antecedentes sociais da vítima.

Vale a pena salientar que alguns veredictos, no sentido absolutório, podem ficar mais a dever à estrutura do sistema penitenciário do que, propriamente, ao crime em si: são decisões por exclusão. Dito de outra forma: certas variáveis adquirem mais força em detrimento das falhas e lacunas de outras.

No que se refere aos fatores de condenação, é possível afirmar, sem sombra de dúvida, que, no topo da pirâmide, jaz uma condenação em definitivo do acusado por crime de maior potencial ofensivo. O repúdio à violência fez-se marcante e presente para ambos os sexos: a reincidência não é suportada pelos jurados. (FARIAS; VAINSENCHER, 1997, p. 21)

Esses posicionamentos suportam a intenção do presente artigo, de demonstrar que os jurados são facilmente conduzidos ao resultado final do julgamento. Este argumento é confirmado, também, no tocante ao acordo prévio entre as partes:

Mais grave ainda é o acordo para condenar o réu. Ferem-se os princípios da soberania dos vereditos, da competência para o julgamento de crimes dolosos contra a vida e da plenitude de defesa. [...]

Por vezes, podem-se encontrar situações teratológicas em plenário do júri, sem que o juiz presidente interfira, em favor do acusado. Este, em seu interrogatório, ilustrando, sustenta a negativa de autoria ou uma base absolutória (legítima defesa, v. g.). Entretanto, durante os debates, 
acusação e defesa acordam ser o melhor caminho a condenação por homicídio simples ou privilegiado, desprezando, por completo, o desejo de ser absolvido, manifestado expressamente pelo réu. O que permite ao magistrado não zelar pela plenitude de defesa? Pensamos ser injustificada a posição de acolher o determinado pelas partes, na medida em que inexiste transação nesse cenário. Ao contrário, detectado o acordo em prejuízo do desejo do réu, deve este ser declarado indefeso e outro julgamento designado, com defensor diverso cuidando de seus interesses. [...]

Da mesma forma que se espera do juiz presidente a direção da sessão, conduzindo com imparcialidade as questões que lhe forem apresentadas, aguarda-se de cada uma das partes o fiel cumprimento à sua função legal e constitucional. Expor a prova aos jurados é obrigação do Ministério Público. Defender o réu, a todo custo, é a missão da defesa. Ambos devem agir com ética e respeito ao processo, independentemente de formarem suas próprias convicções e linhas de atuação. (NUCCI, 2015, p. 336, 339 e 340, grifo nosso)

Assim, qualquer explicação falaciosa é tomada como verdade por indivíduos potencialmente incapazes de fazer juízo técnico-valorativo, por vezes saindo do plenário convictos de que exerceram a justiça ao sobreporem suas verdades subjetivas aos fatos reais do processo.

Como bem dito acima, não há espaço para transação quanto aos crimes dolosos contra a vida, pois tanto o Ministério Público, como titular da persecução penal, quanto a defesa, não dispõem do direito subjetivo que se debate no processo, motivo pelo qual a negociação sobre a condução dos debates se mostra afrontosa à ordem constitucional vigente.

Não obstante, a acusação deve ater-se aos limites impostos pela decisão de pronúncia, não podendo postular sobre as qualificadoras que não foram ali arguidas (NUCCI, 2015, p. 556). Elas estão dispostas no art. 121, § º , do CP, e são:

I - mediante paga ou promessa de recompensa, ou por outro motivo torpe;

II - por motivo fútil;

III - com emprego de veneno, fogo, explosivo, asfixia, tortura ou outro meio insidioso ou cruel, ou de que possa resultar perigo comum;

IV - à traição, de emboscada, ou mediante dissimulação ou outro recurso que dificulte ou torne impossível à defesa do ofendido;

V - para assegurar a execução, a ocultação, a impunidade ou vantagem de outro crime;

$\mathrm{VI}$ - contra a mulher por razões da condição de sexo feminino; 
VII - contra autoridade ou agente descrito nos arts. 142 e 144 da Constituição Federal, integrantes do sistema prisional e da Força Nacional de Segurança Pública, no exercício da função ou em decorrência dela, ou contra seu cônjuge companheiro ou parente consanguíneo até terceiro grau, em razão dessa condição.

A consequência da configuração de uma qualificadora no crime de homicídio é alterar os limites de pena, passando de seis a vinte anos para doze a trinta anos. Ademais, garante ao fato o caráter de hediondo, nos termos do art. 1ํㅡ, I, da Lei $n^{\circ}$ 8.072/90 (Lei dos Crimes Hediondos), tornando-o insuscetível de anistia, graça, indulto e fiança (art. $2^{\circ}$, I e II, da LCH).

No tocante à execução da pena, a progressão de regime dar-se-á após o cumprimento de $40 \%$ (quarenta por cento) da pena, se for primário, 50\% (cinquenta por cento) da pena se, mesmo primário, houve resultado morte, ou se for condenado por exercer o comando, individual ou coletivo, de organização criminosa estruturada para a prática do crime hediondo.

Passará ao cumprimento de 60\% (sessenta por cento) da pena se for reincidente na prática de crime hediondo ou equiparado, e de 70\% (setenta por cento) da pena, se for reincidente em crime hediondo ou equiparado com resultado morte (art. 112, V, VI, VII e VIII, da LEP - alterações dadas pela Lei n. 13.964/2019).

Além disso, os condenados por crime hediondo com resultado morte que cumprem pena em regime semiaberto não terão autorização para saída temporária do estabelecimento, sem vigilância direta, por expressa vedação trazida no art. 122, $§ 2^{\circ}$, da LEP.

Essas breves exposições buscam reafirmar as consequências que argumentos vazios de técnica, respeito e humanidade podem causar ao réu, assim como à vítima, que pode não ter seu direito à resposta judicial contemplado com dignidade.

Há, também, clara violação à garantia constitucional disposta ao Conselho de Sentença de ter seus vereditos como soberanos, pois não há soberania quando faltam meios de apreciar as provas e ocorre condução estratégica, tratando-se, na realidade, de resultado obtido mediante indução (NUCCI, 2015, p. 35-336).

As qualificadoras subjetivas, quais sejam, mediante paga ou promessa de recompensa, ou por outro motivo torpe e por motivo fútil, são possivelmente as que mais geram aberrações jurídicas ante ao ambiente vago que foram deixadas pelo 
legislador, que não definiu completamente o motivo torpe e não deu qualquer explicação ou exemplo sobre o motivo fútil, deixando as suas definições a cargo da doutrina e da imaginação das partes, pois há aqueles que se utilizam do título de leigos carregado pelos jurados para macular os termos técnicos, incluindo situações completamente distintas às definições trazidas pelas qualificadoras.

Como exemplo prático, foram realizadas entrevistas com quarenta e oito jurados da comarca de Recife/PE. Destacaram que 19\% (dezenove por cento) dos homens afirmaram possuir dificuldades causadas pelo desconhecimento técnico da legislação, como, por exemplo, diferenciar as hipóteses de legítima defesa, ou identificar a presença do dolo na conduta do acusado (FARIAS; VAINSENCHER, 1997, p. 249 e 251).

Ante o exposto, verifica-se que o Conselho de Sentença não é inteiramente apto para compreender e valorar os argumentos sobre as qualificadoras, bem como sobre 0 homicídio privilegiado, já que apresenta dificuldades básicas de cognição, como, por exemplo, identificar a presença de dolo na conduta do acusado, que é básica para a simples definição da competência do tribunal do júri.

Há de se considerar também que a acusação pode se aproveitar do que a mídia veicula sobre o processo, além de se valer do Direito Penal do autor:

Outro fator indicativo advém das manchetes divulgadas pela imprensa, que costumam colocar: "Fulano de Tal será julgado pelo Tribunal do Júri", ou "Será julgado hoje o mendigo que matou o comerciante" ... Por isso não se pode perder de vista a lição de Ferrajoli, para quem delinquente não é aquela pessoa que, segundo as circunstâncias, opiniões ou contingentes relações de força, pode ser etiquetada como imoral, perigosa, infiel ou inimiga, mas a que é identificada como responsável por um delito. [...]

...o que mais importa é o autor do fato criminoso, e não o próprio fato cometido pelo acusado. [...]

O réu é visto e colocado como um desviante, isto é, trazendo a questão para o contexto antropológico, é a "pedra que os construtores rejeitam": "...a anomalia, a pedra que os construtores rejeitam, é removida da ordem estruturada da sociedade e levada a representar a simples unidade da própria sociedade, conceitualizada como homogênea e não como um sistema de posições sociais heterogêneas". (STRECK, 2001, p. 118-119, grifos do autor) 
No que tange à abordagem das partes sobre a tese do homicídio privilegiado, as disparidades são mais nítidas, pois não se respeita a tipicidade formal.

Não é comum que o Ministério Público possua a tese de homicídio privilegiado no seu rol de fundamentos, por se tratar de argumento basicamente atrelado à defesa, por meio do qual o acusado terá sua pena diminuída, nos termos do art. $121, \S 1^{\circ}$, do CP: "Se o agente comete o crime impelido por motivo de relevante valor social ou moral, ou sob o domínio de violenta emoção, logo em seguida a injusta provocação da vítima, o juiz pode reduzir a pena de 1/6 (um sexto) a 1/3 (um terço)".

Considerando ser um tipo provido de várias elementares - relevante valor social ou moral, ou domínio de violenta emoção, logo em seguida a injusta provocação da vítima -, é comum observar interpretações distantes da tecnicidade adequada. "Já não se fala da norma, mas do sentido que a essa norma foi dado pelo intérprete" (STRECK, 2001, p. 128).

Como exemplo, a defesa se aproveita da posição remota do Conselho de Sentença sobre as discussões jurídicas para sustentar que a expressão logo em seguida alcança 0 transcurso de dias entre a injusta agressão da vítima e 0 ato homicida, o que está, sem dúvidas, muito destoante da posição sustentada pela doutrina e pelos tribunais.

Contra a decisão dos jurados que se manifeste contrária às provas contidas nos autos cabe recurso de Apelação, nos termos do art. 593, III, $d$, do CPP, que trata desse tipo de decisão, tendo como consequência a condução a novo julgamento (art. 593, § $3^{\circ}$, do CPP). Nesse sentido, os precedentes:

PENAL E PROCESSUAL PENAL. APELAÇÃO CRIMINAL. RECONHECIMENTO PELOS JURADOS DE HOMICÍDIO PRIVILEGIADO. DECISÃO DOS JURADOS MANIFESTAMENTE CONTRÁRIA À PROVA DOS AUTOS. NOVO JULGAMENTO PELO TRIBUNAL DO JÚRI. I - O conjunto probatório não permite acatar a tese levantada pela Defesa do acusado de homicídio privilegiado, diante do amplo lapso temporal situado entre a suposta injusta provocação e o cometimento do crime, descaracterizando-se, assim, a reação imediata do agente, nos termos do art. $121, \$ 1^{\circ}$, do Código Penal. II - Revelam-se inquestionáveis a materialidade do fato típico constante dos autos e a autoria delitiva, comprovada através da confissão do próprio acusado e de todo conjunto probatório dos autos. 
III- Apelo provido. Decisão Unânime. (AP n. 0002396-36.1999.8.17.0001 PE, 3ํo Câmara Criminal, 29/8/2011, grifo nosso)

PROCESSO PENAL. HOMICÍDIO PRIVILEGIADO RECONHECIDO PELO JÚRI NÃO CONFIGURADO. DECISÃO CONTRÁRIA ÀS PROVAS DOS AUTOS. Não tendo sido a reação do agente imediatamente à suposta provocação da vítima, havendo entre ambas lapso considerável de tempo, não há como reconhecer-se a ocorrência do homicídio privilegiado, nos termos do art. $121, \S 1^{\circ}$, do Código Penal. Recurso provido para submeter o réu a novo julgamento pelo Tribunal do Júri. (Ap n. 0153201999 MA, Rel. Mário Barros Ferraz, 1a Câmara Criminal, julgado em 15/8/2000, publicado em 28/9/2000, grifo nosso)

Pelo acima exposto, é de se considerar que a ausência de técnica e zelo pelas partes diante dos verdadeiros agentes do processo, acusado e vítima, pode causar impactos enormes em suas vidas. O réu poderá ser submetido a novo julgamento, tendo que reviver o momento de reprovação social e até mesmo de possível encenação conduzida pelas partes, assim como a vítima terá que retornar ao momento do crime, expondo suas fragilidades. Os familiares e também são atingidos pelos julgamentos, pois há uma mobilização geral em face do momento.

Esse "novo" júri será composto por outros jurados, mas como o espetáculo será realizado pelos mesmos "atores", em cima do mesmo "roteiro" e no mesmo cenário, a chance de o resultado final ser igual é imensa.

E, nesse "novo" júri, a decisão é igual à anteriormente prolatada e, portanto, novamente divorciada da prova dos autos. Duas decisões iguais, em manifesta dissociação com o contexto probatório.

Poderá haver então novo recurso, aduzindo que novamente os jurados decidiram contra a prova dos autos? Não, pois a última parte do $\S 3^{\circ}$ do art. 593 veda expressamente essa possibilidade. Logo, se no segundo júri eles decidirem novamente contra a prova dos autos, não caberá recurso algum.

Os jurados podem então decidir completamente fora da prova dos autos sem que nada possa ser feito. Possuem o poder de tornar o quadrado, redondo, com plena tolerância dos Tribunais e do senso comum teórico, que se limitam a argumentar, fragilmente, com a tal "supremacia do júri", como se essa fosse uma "verdade absoluta", inquestionável e insuperável. (LOPES JR., 2012, 1.052-1.053, grifo nosso)

Denota-se que há violação ao princípio básico constitucional da dignidade da pessoa humana, até mesmo à conservação da imagem, disposto no art. 5ํ, X, da CF, 
pois réu e vítima estarão novamente à disposição do público e da sociedade para julgamentos morais, tendo suas vidas atuais e pregressas invadidas por grande número de desconhecidos, sem deterem qualquer tipo de controle sobre isso.

Apesar disso, as discussões sobre o instituto tendem a ser abafadas com o argumento de que o poder constituinte originário outorgou ao Conselho a soberania de decidir de acordo com a sua livre convicção.

\subsection{A insegurança do Conselho de Sentença no momento da votação dos quesitos}

A Lei 11.689/2008 conferiu mudanças consubstanciais aos quesitos, que representam mais um dos problemas do instituto. São apresentados em forma de perguntas, às quais cabem a resposta sim ou não.

Os arts. 482 a 491 do CPP dispõem sobre o modo de elaboração dos quesitos e a condução das votações. O parágrafo único do art. 482, do CPP, aduz que as perguntas deverão ser feitas de forma afirmativa, simples e distinta, para que possam ser respondidas com clareza e precisão suficientes, e o juiz presidente considerará, na elaboração, os termos da pronúncia e de decisões posteriores, o interrogatório do réu e as alegações das partes em plenário.

Diante desse artigo, mesmo que as partes conduzam seus argumentos de forma equivocada, pretensiosa, as teses serão dispostas aos jurados para votação, que poderão comprometer o resultado do julgamento com base em afirmações isentas de qualquer solidez, as vezes por não compreenderem o significado dos argumentos.

Não suficiente, ainda há aqueles que podem esquecer em que mão está a ficha contendo o sim e o não no momento da votação de cada quesito apresentado pelo juiz presidente, enfatizando a insegurança e falibilidade do tribunal do júri como um todo.

O percentual que leva o indivíduo a uma condenação é de $\mathbf{5 7 , 1 4 \%}$ (cinquenta e sete vírgula catorze por cento) de certeza, relativa à maioria necessária para concluir um quesito. 
Interessante, ainda, como um dos principais pilares em comum do Direito Penal e do processo penal cai por terra sem que ninguém o proteja. $O$ in dubio pro reo é premissa hermenêutica inafastável do Direito Penal e, no campo processual, juntamente com a presunção de inocência, norteador da axiologia probatória. Ao mesmo tempo informa a interpretação da norma penal e a valoração da prova no campo processual

Quando os jurados decidem pela condenação do réu por $4 \times 3$, está evidenciada a dúvida, em sentido processual. Significa dizer que existe apenas $57,14 \%$ de consenso, de convencimento. Questiona-se: alguém admite ir para a cadeia com 57,14\% de convencimento? Elementar que não.

A sentença condenatória exige prova robusta, alto grau de probabilidade (de convencimento), algo incompatível com um julgamento por 4x3. Ou seja, ninguém poderia ser condenado por $4 \times 3$, mas isso ocorre diuturnamente no Tribunal do Júri, pois lá, como diz o jargão forense, o in dubio pro reo passa a ser lido pelos jurados como in dubio "pau" no reo... (LOPES JR., 2012, p. 1053)

É considerada a proporção 4x3 nas respostas do Conselho de Sentença a cada quesito por conta do disposto no art. 489, do CPP, o qual impõe que as decisões serão tomadas por maioria dos votos. Assim, no momento em que o juiz presidente encontra a maioria dos votos para sim ou para não - no caso, 4 votos -, encerra a votação para garantir o sigilo constitucional.

A presunção de inocência também é garantia constitucional e está disposta no art. 5, LVII, da CF, com o texto "ninguém será considerado culpado até o trânsito em julgado de sentença penal condenatória". É inconcebível que o indivíduo seja condenado diante de incertezas dos jurados, mas isso encontra sustentação na prevalência do princípio in dubio pro societate, o qual permite que, em caso de dúvida, ganhe relevância a posição social, desde a decisão de pronúncia.

Há forte crítica doutrinária a esse ponto:

Ora, se o juiz togado dispõe de até 10 (dez) dias para proferir seu julgamento - em regra acompanhou toda a instrução processual - não se justifica exigir que o corpo de jurado na maioria das vezes leigo, em prazo exíguo, proferirá veredicto em processo que o próprio Juiz togado pronunciou com dúvida. Não é porque o jurado faz um julgamento de consciência, que o mesmo deve ser exposto às mazelas de uma instrução - não digo malfeita - mas insuficiente, marcada pelo signo da dúvida, quando o próprio legislador estabeleceu constitucionalmente o princípio da presunção de inocência donde decorre o "in dubio pro reo", tendo seu registro literal no art. 386, VI do CPP. [...] 
Parece-me claro que à sociedade não interessa julgar seus pares, quando apesar de todos os esforços da acusação, persiste dúvida, não é justo simplesmente transferir esta dúvida para o juiz leigo. Esmiuçando, se o Estado com todo o seu poderia de investigação não logrou êxito em espancar dúvida durante a instrução processual, sendo forçoso reconhecer sua ineficiência neste aspecto, possa transferir ao corpo de jurado o julgamento de um do povo sem provas razoáveis, isto não combina com o estágio avançado da sociedade que dispõe que melhores instrumentos de investigação, ficando claro que não atende ao espírito constitucional do legislador de 1988. (SILVA, 2016, p. 417 e 420)

Todavia, a garantia dada pelo constituinte originário ao Conselho de Sentença de ter vereditos soberanos e sem necessidade de os fundamentar também contribui para os problemas debatidos pela comunidade jurídica.

A possibilidade de votar com base na íntima convicção autoriza os jurados a deixarem de lado o conjunto probatório demonstrado em plenário e conduzir o resultado com base em diversos fundamentos de ordem pessoal, indo contra o disposto no art. 93, IX, da CF, que dispõe, in verbis, que "todos os julgamentos dos órgãos do Poder Judiciário serão públicos, e fundamentadas todas as decisões, sob pena de nulidade...".

Considerando que, por si só, o instituto é complexo e composto por diversas contradições na própria Constituição Federal, é necessário clamar prudência das partes para que materializem em suas falas argumentos racionais e atinentes aos autos, deixando de lado eventuais espetáculos ou embates desprovidos de substancialidade e materialidade, considerando-se, em especial, que a decisão dos jurados implicará em fortes consequências para a vida do réu e da vítima sobrevivente do crime.

A esse respeito, cada palavra ou expressão aquém do conhecimento básico dos jurados, ou cada interpretação manipulada da norma penal, levará dúvidas ao Conselho de Sentença, materializadas no momento crucial de votação dos quesitos.

\section{CONSIDERAÇÕES FINAIS}

A existência do tribunal do júri constitui cláusula pétrea, inserida no art. 5으, XXXVIII, da CF. Não obstante, os crimes de competência do Tribunal do Júri devem ser analisados de forma bastante crítica, já que colocam em xeque um valioso bem jurídico: a vida. 
O instituto constitui-se, por vezes, como um palco de encenações, em que as partes podem distorcer o Direito, utilizar de contradições inseridas na própria Constituição Federal, que dificilmente serão repreendidas pelo juiz presidente ou simplesmente ignoradas pelos jurados, diante da ausência de conhecimento técnicojurídico.

Por vezes, o Conselho de Sentença dirige-se à sala secreta para votação dos quesitos corroborando normas que não existem, pois foram conduzidas e alteradas de acordo com a conveniência sustentada pelas partes.

Não é falaciosa a afirmação de que o corpo de jurados não consegue assimilar diferenças profundas na discussão de uma qualificadora, ou que seja essencial a presença de todas as peças formadoras do homicídio privilegiado para a sua configuração.

Além do mais, os integrantes do Conselho de Sentença são livres para votar por motivos pessoais no momento do julgamento dos quesitos, retornando ao período arcaico em que vigorava o Direito Penal do autor. Tal aberração inicia-se na possibilidade de recusa dos membros do Conselho de Sentença pelas partes, que optam por aqueles que possivelmente irão coadunar com os próprios interesses - mais uma estratégia de plenário.

Em alguns julgamentos, é notória a manifestação, pelas partes, de argumentos ausentes de materialidade e distantes de um grau adequado de compreensão por parte dos jurados, criando um teatro simbólico onde triunfará aquele que possuir as melhores técnicas de convencimento, levando a absolvições ou condenações equivocadas, e afastando-se, desta feita, do ideal pretendido de justiça buscado por todo o ordenamento.

\section{REFERÊNCIAS}

BRASIL. Constituição (1988). Constituição da República Federativa do Brasil de 1988. Brasília/DF, CF: Senado Federal: Centro Gráfico, 1988.

. Decreto-lei no 2.848, de 07 de dezembro de 1940. Código penal. Rio de Janeiro/RJ, 7 de dezembro de 1940. DOU de 31/12/1940, Seção 1, Página 23911. 
. Decreto-lei no 3.689, de 03 de outubro de 1941. Código de processo penal. Rio de Janeiro/RJ, 3 de outubro de 1941. DOU de 13/10/1941, Seção 1, Página 19699.

Lei de 20 de setembro de 1830 . Sobre o abuso da liberdade da imprensa. Rio de Janeiro/RJ, 20/9/1830. Coleção de Leis do Império do Brasil - 1830, Vol. 1 pt I, Página 35. Disponível em: <http://www2.camara.leg.br/legin/fed/lei_sn/18241899/lei-37987-20-setembro-1830-565654-publicacaooriginal-89402-pl.html>. Acesso em: 05 nov. 2018.

. Lei no 11.689, de 09 de junho de 2008. Altera dispositivos do Decreto-Lei no 3.689, de 3 de outubro de 1941 - Código de Processo Penal, relativos ao Tribunal do Júri, e dá outras providências. Brasília/DF. DOU de 10/6/2008, Seção 1, Página 1. Disponível em: <http://www.planalto.gov.br/ccivil_03/_Ato20072010/2008/Lei/L11689.htm>. Acesso em: 07 nov. 2018.

. Supremo Tribunal Federal. Pesquisa de Jurisprudência. Disponível em: <http://www.stf.jus.br/portal/jurisprudencia/pesquisarJurisprudencia.asp>. Acesso em: 14 nov. 2018.

CABRAL JR, Luciano Roberto Gulart. A INCONSTITUCIONALIDADE DA VOTAÇÃO SECRETA DO TRIBUNAL DO JÚRI. Revista espaço acadêmico, Maringá, n. 191, p. 83-96, abr. 2017. Mensal.

DUTRA, Fabio. Algumas questões sobre o tribunal do júri. Disponível em: <http://www.tjrj.jus.br/c/document_library/get_file?uuid=b807f95b-11fa-4404-b2f7acbd9d8394bb\&groupld=10136>. Acesso em: 28/07/18.

FARIAS, Angela Simões de; VAINSENCHER, Semira Adler. Júri popular: algumas possibilidades de condenação ou absolvição. Revista de informação legislativa, Brasília, v. 133, n. 34, p.17-22, jan. 1997.

ISHIDA, Válter Kenji. Processo penal: de acordo com a reforma processual penal. São Paulo: Atlas, 2009.

LOPES JR., Aury. Direito processual penal. 9. ed. São Paulo: Saraiva, 2012.

NUCCI, Guilherme de Souza. Tribunal do júri. 6. ed. Rio de Janeiro: Forense, 2015.

OLIVEIRA, Eugênio Pacelli de. Curso de processo penal. 12. ed. Rio de Janeiro: Lumen Juris, 2009.

OLIVEIRA, Laĺs Mendes. Tribunal do júri e o subjetivismo inquisitivo. De Jure: Revista Jurídica do Ministério Público do Estado de Minas Gerais, Belo Horizonte, v. 16, n. 28, p. 235-251, jan. 2017. Semestral. 
SANTOS NETO, Higino Lopes dos. A participação popular no Tribunal do Júri. In: OLIVEIRA, Tarsis Barreto; OLIVEIRA, Enio Walcácer de. Escritos de ciências criminais. Curitiba: Prismas, 2017. p. 61-87.

SILVA, Nilson Afonso da. A superação do princípio "in dubio pro societate" no rito do tribunal do júri. In: OLIVEIRA, Tarsis Barreto; OLIVEIRA, Enio Walcácer de; VIVEIROS, Estefânia. Efetividade da tutela jurisdicional \& técnicas processuais. São Paulo: Perse, 2016. p. 409-424

STRECK, Lenio Luiz. Tribunal do júri: símbolos e rituais. 4. ed. Porto Alegre: Livraria do Advogado, 2001. 